\title{
ABCB1 gene polymorphisms is not associated with drug- resistant epilepsy in Romanian children
}

\section{Absenţa asocierii unor polimorfisme ale genei ABCB1 şi epilepsiile rezistente la tratamentul antiepileptic la copiii din România}

\author{
Anamaria Todoran Butila ${ }^{1 *}$, Anca $\mathrm{Sin}^{2}$, Elisabeta Racoş Szabo ${ }^{3}$, Cristian Micheu ${ }^{4}$, \\ Valeriu G. Moldovan ${ }^{1}$, Septimiu Voidazan ${ }^{5}$, Claudia Bănescu ${ }^{1}$
}

1. Department of Genetics, University of Medicine and Pharmacy, Târgu Mureş, Romania; 2. Department of Cell Biology, University of Medicine and Pharmacy, Târgu Mureş, Romania; 3. Department of Psychiatry, University of Medicine and Pharmacy, Târgu Mureş, Romania; 4. Clinic of Paediatric Neurology and Psychiatry Târgu Mureş, Romania; 5. Department of Epidemiology, University of Medicine and Pharmacy, Tîrgu Mureş, Romania

\begin{abstract}
Background: P-glycoprotein (P-gp), a drug efflux transporter, encoded by the gene MDR1 ABCB1 multidrug resistant, reduces the penetration through the brain by the AEDs. Overexpression of Pgp in blood-brain barrier in epileptic patients play an important rol in pharmacoresistance. The aim of this study was to evaluate a possible association between C1236T and G2677T ABCB1 gene polymorphisms and drug-resistant epilepsy in Romanian children. Material and Methods: A total of 194 children with epilepsy hospitalized in the Paediatric Neurology and Psychiatry Clinic in Tirgu Mureş and 153 healthy controls were included in this study. Of the initial group, those cases that met the criteria for idiopathic and cryptogenic epilepsies (114 cases) were stratified in 31drug-resistant and 83 drug-responsive patients. The C1236T and G2677T genetic polymorphisms were assessed by RFLP-PCR (polymerase chain-restriction fragment length polymorphism) followed by gel electrophoresis. Results: Molecular analysis of ABCBI gene polymorphism identified 1236CT heterozygous to be highly represented in drug-responsive group, with a p value of 0.001. Also, in idiopathic epilepsy subgroups (with partial and generalized type of seizures), in case of 1236TT and CT genotypes we found highly significant differences between drug-responsive patients and those resistant to antiepileptic treatment (p-0.003 and p-0.002 respectively). No association between G2677T polymorphism and total epilepsy was found. Conclusions: Our results show that MDR1 C1236T and G2677T polymorphisms are not associated with drug-resistant epilepsy in the study population, but 1236TT and 1236CT genotype variants and also 2677TT were found to be significantly associated with drug-responsive idiopathic epilepsy.
\end{abstract}

Keywords: C1236T, G2677T, ABCB1 gene, epilepsy, children

\footnotetext{
*Corresponding author: Anamaria Todoran Butila, Department of Genetics, University of Medicine and Pharmacy, Târgu Mureş, Romania, e-mail: eleonora.anetodoranb@gmail.com
} 


\section{Rezumat}

Introducere: Glicoproteina $P$, un transportor de eflux de substanţe, codificată de gena multidrug resistant MDR1 ABCB1, reduce penetrarea creierului de către antiepileptice. Supraexprimarea proteinei la nivelul barierei hematoencefalice la pacienţii epileptici, joacă un rol important în farmacorezistenţă. Scopul acestui studiu a fost acela de a evalua o posibilă a sociere între polimorfismele genice ABCB1 C1236T și G2677T si epilepsia rezistentă la tratamentul antiepileptic la copiii din România. Material și metodă: studiul a inclus 194 de copii cu epilepsie internaţi în Clinica de Neurologie şi Psihiatrie Pediatrică din Targu Mureşşi un lot control compus din 153 de copii sănătoşi. Din lotul total, cei care au întrunit criteriile pentru forme de epilepsii idiopatice și criptogenice (114 cazuri) au fost grupați în: 31 de pacienți cu epilepsie rezistentă la tratament şi 83 pacienţi cu forme responsive. Pentru determinarea frecvenţei alelice şi a genotipurilor s-a utilizat tehnica PCR-RFLP urmată de elecroforeza în gel. Rezultate: forma heterozigotă pentru C1236T (1236CT) a fost semnificativ reprezentată în grupul responsiv la tratament, cu o valoare p de 0.001. In epilepsiile idiopatice (forme parţiale sau generalizate), genotipurile 1236TT si $1236 C T$ au fost identificate ca fiind semnificativ statistic asociate formelor responsive la tratament (p-0.003 respectiv p-0.002). Nu a fost identificată nici o asociere intre polimorfismul genic G2677T și lotul epileptic studiat. Concluzii: Rezultatele noastre arată că polimorfismele MDR1 C1236T şi G2677T nu sunt asociate cu epilepsiile rezistente la tratament în rândul populației studiate, în schimb genotipurile 1236TT şi 1236CT precum şi $2677 T T$ s-au dovedit a fi asociate cu formele idiopatice de epilepsii responsive la tratament.

Cuvinte cheie: C1236T, G2677T, gena ABCB1, epilepsie, copii

Received: $16^{\text {th }}$ May 2015; Accepted: 19 $9^{\text {th }}$ September 2015; Published: $14^{\text {th }}$ December 2015

\section{Introduction}

Epilepsy is a condition characterized by two or more recurrent seizures which are unprovoked by any immediate identified cause. Despite significant advances in terms of antiepileptics, one third of epileptic patients still remain drug-resistant.[1] Resistance to AEDs (antiepileptic drug) increases the morbidity and mortality risk for these patients. The mechanism leading to resistance towards antiepileptic treatment is complex and still, to this date, is incompletely deciphered. Drug-resistance depends on several factors, such as aetiology, type of AED medication, epilepsy phenotype, frequency and type of seizures, age of onset, syndrome type, structural cerebral abnormalities, and electroencephalographic discharges. In addition, treatment resistance can be associated with the same genetic factors related to pharmacokinetics and pharmacogenetics of AED. These genetics factors can induce increases in plasma level concentrations either by decreasing elimination or by increasing absorption of the medication and also by facilitat- ing the substance's access to the epileptic foci from the central neurvous system (CNS). Genetic factors may also cause changes in transporters and receptors affecting the therapeutic response. [2] ABC (the ATP-binding cassette) proteins are associated with multiple drug resistance and are members of an energy-dependent protein superfamily. The MDR1 gene (ABCB1) is located on chromosome 7q21.1 and encodes a membrane protein (p-glycoprotein Pgp), found in several tissues such as pancreas, liver, kidney, intestine and in other tissues with excretory or secretory function. Several hypotheses have been issued concerning the aetiology of resistance to antiepileptic drugs. Two concepts are attempting to explain this issue: the first is modification of the action target and the second is modification of the efflux protein function. The first hypothesis is sustained by studies which show the association between pharmachoresistance to treatment and structural damage or anomalies in the neuronal network and in the activity of same neurotransmitters. The second hypothesis incriminated a weak penetration of the AEDs through 
the blood-brain barrier (BBB), where the existing high density of $\mathrm{ABC}$ transporters determines multiple drug resistance.[3] Starting from this idea a non-specific mechanism was suggested, which limits antiepileptic drug efficiency by over-expressing efflux transporters at BBB. $\mathrm{P}$ glycoprotein $(\mathrm{P}-\mathrm{gp}$ ) is the prototype of these transporters.

It is known that almost all seizures are caused by the cumulative action in varying proportions genetic factors (predisposing factors) and environmental factors (precipitating factors). Also, "both, genetic factors and subclinical differences in epilepsy related brain alteration may be involved".'[2] In the genetic causes of epilepsy environmental factors will influence disease expression. Also, the genetic factors is possible to generate in structural lesions of the CNS, epileptogenic potential wich underliyng symptomatic epilepsies.[4]

In 1995, Thisel et al. suggested the absence of response to antiepileptic treatment to be secondary to a reduction in drug penetration into the CNS.[5] In this study the authors noticed an increased expression of MDR1 in the brain tissue of patients undergoing surgery. Dombrovski et al. in a study on patients diagnosed with refractory epilepsy, treated by temporal lobectomy, demonstrated an increased expression of MDR1 in endothelial cells of the BBB.[6]

Several single nucleotide polymorphisms (SNPs) have been identified in the ABCB1 gene. Among them, C3435T, C1236T, G2677T, G2667A, T129C polymorphism are the most studied in epilepsy. Due to the potential involvement of this gene in resistant epilepsy, a large number of studies have suggested these polymorphisms to be associated factors for drug-resistant epilepsy. Siddiqui et al. [7] performed a large study on Caucasian population analysing three single nucleotide polymorphisms (C1236T, G2677T and C3435T) and found a significant association between $\mathrm{C} 3435 \mathrm{~T}$ polymorphism and drug-resistant epilepsy. On the other hand, the association among drug therapy response and C3435T genotype observed in these studies was not confirmed by other studies that included patients with similar ethnic characteristics. [8-11].

To our knowledge, no data are available regarding the association between C1236T and G2677T polymorphisms and epilepsy in Romanian children. The aim of this study was to evaluate a possible association between C1236T and G2677T ABCB1 gene polymorphisms and drug-resistant epilepsy in Romanian children.

\section{Material and Methods}

\section{Patients and controls}

The study protocol was approved by the Ethics Committee of the University of Medicine and Pharmacy of Tirgu Mures. A written informed consent was signed by each parent or legal tutor of all children included in the present study.

We analysed a number of 194 patients diagnosed with various forms of epilepsy, hospitalized in the Paediatric Neurology and Psychiatry Clinic Tirgu Mureş, between 2011 and 2014. Epilepsy diagnosis was made according to the definition of epilepsy and ILAE (International League Against Epilepsy) classification.[12] Epileptic children were divided according to aetiology, in idiopathic (74 cases), cryptogenic (40 cases) and symptomatic (80 cases) groups, as well as by type of epileptic seizure, namely partial and generalized. Idiopathic epilepsy represent a group of epileptic syndromes predominantly genetic or presumed genetic origin, in which patients had a normal structural brain and a normal neurological examination; symptomatic epilepsy are those cases, with structural or metabolic causes and cryptogenic epilepsies are defined as an epilepsy of presumed symptomatic unknown causes. Of the initial group, for this study those cases that met the criteria for idiopathic and cryptogenic epilepsies (114 cases) (previously diagnosed and treated) were selected, aged 1.1 years to 18 years (49 girls and 65 boys), mean 
age $8.98 \pm 2.9$ years. We also selected a number of 153 healthy controls ( 89 girls and 64 boys) aged between 2.1 to 17.6 years. Controls were chosen randomly, all being unrelated healthy children with no neuropsychiatric diseases, no personal or family history of seizures, and were recruited from the Paediatric department. All epileptic patients included in the study had specific epileptiform discharges on EEG and all were on stabile treatment with one, two or more antiepileptic drugs in maximum tolerated dose and adequate AED schedules for at least one year. The exclusion criteria were noncompliance of AED therapy and symptomatic epilepsies.

The selected 114 patients were stratified in two groups according to their antiepileptic drug response (drug-responsive and drug-resistant). Drug-responsive group consisted of 83 patients that were seizure free on monotherapy or combination-therapy for at least 12 months or for a three-times longer period compared to the inter-seizure interval (of the relapsed seizures). In accordance with a recent Task Force of the ILAE Commission on Therapeutic Strategies, drug-resistant patients (our group of 31 patients) were

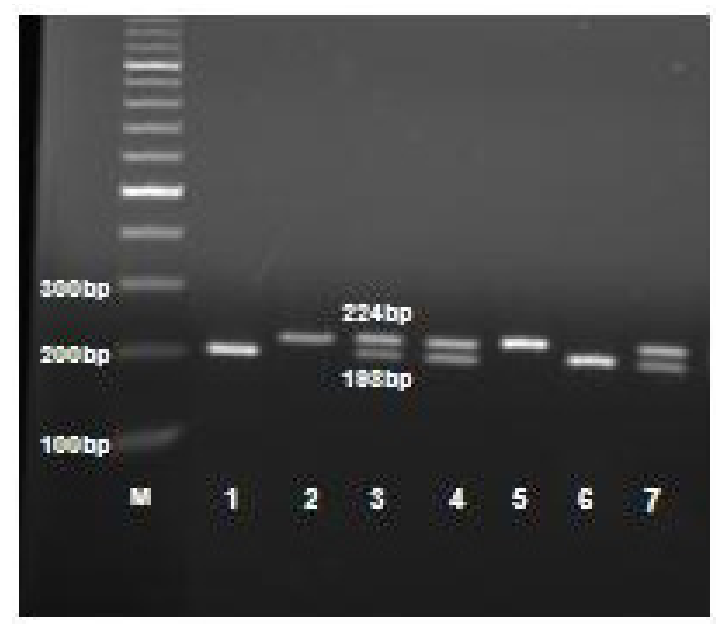

a) considered if they were not seizure free even after adequate trial with two, three or more tolerated, appropriately chosen AED schedules was instituted.[13,14]

\section{Genotyping procedure}

Genomic DNA was obtained from peripheral blood samples using a Zymo Beads Genomic DNA kit (Zymo Research). The ABCB1 genotypes were determined by PCR-RFLP (polymerase chain-restriction fragment length polymorphism) assay. Primers, restriction enzymes and PCR protocols for G2677T were the same as described by Dong L et al. [15] but with a minor modification regarding $\mathrm{C} 1236 \mathrm{~T}$ PCR protocol: initial denaturation at $95^{\circ} \mathrm{C}$ for 5 minutes, followed by 40 cycles of denaturation at $95^{\circ} \mathrm{C}$ for 30 seconds, anneling for 30 seconds at $59^{\circ} \mathrm{C}$, extension at $72^{\circ} \mathrm{C}$ for 30 seconds, and a final extension at $72^{\circ} \mathrm{C}$ for 5 minutes. All restriction enzymes used in this study were supplied by Fermentas. The resulting fragments were separated by electrophoresis, using standard 2\% agarose gels stained with ethidium bromide. (Figure 1)

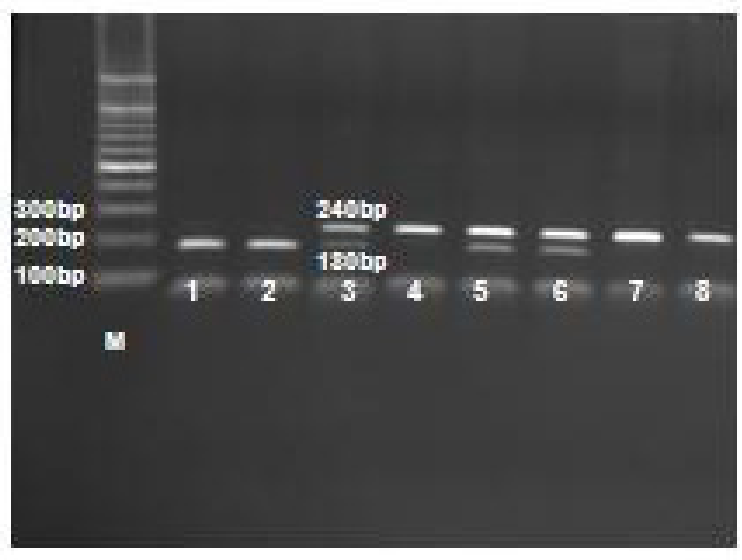

b)

Fig. 1 Determination of ABCB1G2677T and C1236T genotypes by gel electrophoresis, following PCRRFLP. a) PCR amplifications of locus G2677T digested by BanI. M: marker; GT: 3,4,7; GG: 1,6; TT: 2,5 b) PCR amplifications of locus C1236T digested by EcoO109I. M: marker; CT: 3,5,6; CC: 1,2; TT: 4,7,8 


\section{Statistical analysis}

For statistical analysis we used SPSS software, version 17.0 (Statistical Package for Social Sciences), considering statistically significant a $\mathrm{p}$ value of less than $<0.05$. A chi-square test was used to evaluate the Hardy-Weinberg equilibrium. Fisher's exact test performed on a contingency table with was used to compare allele and genotype frequencies between the epileptic, idiopathic and symptomatic epileptic subgroups and also between partial and generalized type of epilepsy. OR (odds ratio) was calculated to demonstrate the probability or susceptibility to drug resistance according to the given polymorphism.[16]

\section{Results}

Demographic characteristics of the $83(72,8 \%)$ drug-responsive and $31(27,2 \%)$ drug- resistant epileptic children are shown in Table I. Age distribution at the time of study and age of onset show a significant difference between groups (p-0.005 and p-0.01 respectively). The onset of epilepsy between the ages of 4-12 has been identified as being representative both in the drug-resistant and drug-responsive epileptic groups. Instead, epilepsy onset above 12 years old was associated in $95.5 \%$ with the total control of seizures. Gender distribution was not significantly different between drug-resistant, drug-responsive and control groups. No statistically significant difference between partial or generalized seizures was observed. Patients with cryptogenic epilepsy had at three times greater risk of developing drug resistant epilepsy than those with idiopathic epileptic syndromes (p-0.008, OR:3.16, 95\% CI:1.34-7.45). The type and causes of epilepsy that were included in study follow the classification offered by Shorvone et al, 2011 [17] and

Table I. Demographical data of patients

\begin{tabular}{|c|c|c|c|c|c|}
\hline Subgroups & Categories & $\begin{array}{c}\text { Total epileptic } \\
\text { pacientes } \\
(\mathrm{N}=114) \\
\end{array}$ & $\begin{array}{l}\text { Drug-responsive } \\
\qquad(\mathrm{N}-83)\end{array}$ & $\begin{array}{l}\text { Drug-resistant } \\
\text { (N-31) }\end{array}$ & p value* \\
\hline $\begin{array}{l}\text { (years) } \\
\text { median (min-max) }\end{array}$ & - & $8.6(1.1-18)$ & $11.0(1.9-18)$ & $6(2.5-13.3)$ & 0.005 \\
\hline \multirow{2}{*}{ sex, no $(\%)$} & $\mathrm{F}$ & $49(43.0)$ & $33(39.7)$ & $16(51.6)$ & - \\
\hline & $\mathrm{M}$ & $65(57.0)$ & $50(60.3)$ & $15(48.4)$ & 0.25 \\
\hline Age & $<12$ years & $72(63.1)$ & $46(55.4)$ & $27(87.1)$ & - \\
\hline no $(\%)$ & $>12$ years & $42(36.9)$ & $37(44.6)$ & $4(12.9)$ & 0.001 \\
\hline \multirow{4}{*}{$\begin{array}{l}\text { Age of onset } \\
\text { no }(\%)\end{array}$} & $<1$ year & $16(14.0)$ & $9(10.8)$ & $7(22.6)$ & 0.01 \\
\hline & $1-3$ years & $25(21.9)$ & $15(18.07)$ & $10(32.3)$ & \\
\hline & $4-12$ years & $51(44.7)$ & $38(45.8)$ & 13 (41.9) & \\
\hline & $>12$ years & $22(19.3)$ & $21(25.3)$ & $1(3.22)$ & \\
\hline \multirow{2}{*}{$\begin{array}{l}\text { Type of seizures } \\
\text { no }(\%)\end{array}$} & $\begin{array}{l}\text { Simple partial and } \\
\text { complex }\end{array}$ & $32(28.1)$ & $24(28.9)$ & $8(25.8)$ & - \\
\hline & Generalized & $82(71.9)$ & $59(71.08)$ & $23(74.2)$ & 0.74 \\
\hline \multirow{2}{*}{$\begin{array}{l}\text { aetiology } \\
\text { no }(\%)\end{array}$} & Idiopathic & $74(64.9)$ & $60(49.2)$ & $14(19.4)$ & - \\
\hline & Cryptogenic & $40(35.1)$ & $23(18.8)$ & $17(23.6)$ & 0.008 \\
\hline \multirow{4}{*}{$\begin{array}{l}\text { AED } \\
\text { no }(\%)\end{array}$} & Monotherapy & $70(61.4)$ & $70(84.3)$ & $0(0.0)$ & \\
\hline & 2 drugs & $24(21.1)$ & $10(12.04)$ & $14(45.1)$ & 0.001 \\
\hline & 3 drugs & $15(13.4)$ & $3(3.6)$ & $12(38.7)$ & \\
\hline & 4-5 drugs & $5(4.4)$ & $0(0.0)$ & $5(16.2)$ & \\
\hline
\end{tabular}

AED- antiepileptic drug, *chi test square, Mann Whitney, OR-Odds Ratio, no-number 
Table II. The causes of epilepsies in our patients

\begin{tabular}{|c|c|c|}
\hline & $\mathrm{N}(\%)$ \\
\hline \multicolumn{2}{|c|}{$\begin{array}{ll}\text { pure epilepsies due to single } & \text { autosomal dominant nocturnal frontal lobe epilepsy (ADNFLE) } \\
\text { gene disorders } & \text { generalized epilepsy with febrile seizure plus (GEFS+) } \\
& \text { benign myoclonic epilepsy }\end{array}$} & $\begin{array}{l}2(2.7) \\
2(2.7)\end{array}$ \\
\hline $\begin{array}{l}\text { pure epilepsies with com- } \\
\text { plex inheritance }\end{array}$ & $\begin{array}{l}\text { idiopathic generalized epilepsy (IGE) } \\
\text { - childhood absence epilepsy (CAE) } \\
\text { - juvenile absence epilepsy (JAE ) } \\
\text { - juvenile mioclonic epilepsy (JME) } \\
\text { - generalized tonic clonic epilepsy (GTCS) } \\
\text { - partial idiopathic epilepsy }\end{array}$ & $\begin{array}{l}11(14.9) \\
6(8.1) \\
9(12.2) \\
23(31.1) \\
19(25.7)\end{array}$ \\
\hline 40 cases of cryptogenic epile & psies $\quad$ unknown causes & \\
\hline
\end{tabular}

are described in Table II. From the 74 idiopathic epilepsy selected cases, 19 (25.7\%) were partial type $(84.2 \%$ drug-responsive and $15.9 \%$ drug-resistant forms). Of the 55 (74.3\%) idiopathic generalized epilepsy cases, $80 \%$ presented complete seizure control while under specific treatment while in $20 \%$ of cases we found recurrent seizures (27.3\% GEFS, 9.1\% GTCS, 63.6\% CAE).

$\mathrm{ABCB} 1$ gene's genotype and allele frequencies of the two investigated polymorphisms for both epileptic and healthy children are presented in Table III.
The distribution of MDR1 C1236T and G2677T genotypes within the two groups was not significantly different from that indicated by the Hardy-Weinberg equilibrium. No statistically significant differences were detected for the genotype and allele frequencies of the polymorphisms in the ABCB1 gene between all epileptic patients and healthy controls. $\mathrm{C}$ allele as well as CT and GT genotypes were the most frequent in both groups. Allele and genotype frequency analysis after stratification of epilepsies in idiopathic and cryptogenic showed no statistically

Table III. Genotype and allele frequencies of the polymorphisms in ABCB1 gene for epileptic and healthy children

\begin{tabular}{lcccc}
\hline $\begin{array}{l}\text { SNP } \\
\text { Genotype/allele }\end{array}$ & $\begin{array}{c}\text { Epileptic children } \\
(\mathbf{N}-114)\end{array}$ & $\begin{array}{c}\text { Healthy controls } \\
\text { children } \mathbf{( N - 1 5 3 )}\end{array}$ & p value & OR/95\%CI \\
\hline Exon 12-C1236T & $31(27.2)$ & $40(26.1)$ & - & - \\
CC & $56(49.1)$ & $78(51.0)$ & 0.92 & $0.92(0.51-1.65)$ \\
CT & $27(23.7)$ & $35(22.9)$ & 0.98 & $0.99(0.50-1.97)$ \\
TT & $83(72.8)$ & $113(73.9)$ & 0.84 & $0.94(0.54-1.64)$ \\
CT+TT & $118(51.8)$ & $158(51.6)$ & - & - \\
C & $110(48.2)$ & $148(48.4)$ & 0.97 & $0.99(0.70-1.40)$ \\
T & & & & - \\
Exon 21-G2667T & $30(26.3)$ & $42(27.5)$ & - & $1.03(0.57-1.85)$ \\
GG & $53(46.5)$ & $72(47.1)$ & 0.92 & $1.11(0.57-2.16)$ \\
GT & $31(27.2)$ & $39(25.5)$ & 0.75 & $1.05(0.61-1.83)$ \\
TT & $84(73.6)$ & $111(72.5)$ & 0.83 & - \\
GT+TT & $113(49.5)$ & $156(51.0)$ & - & $1.05(0.75-1.49)$ \\
G & $115(50.5)$ & $150(49.0)$ & 0.74 & \\
T & & & & \\
\hline
\end{tabular}

SNP-single nucleotide polymorphism, OR-odds ratio; CI-confidence interval 
significant difference compared to the control group. For C1236T, CT heterozygotes were identified with a higher frequency among those with idiopathic epilepsy than those with cryptogenic, with no statistical significance. $\mathrm{T}$ allele was more frequent in idiopathic forms for the 2677 locus.

Genotype and allele frequencies of C1236T and G2677T in drug-resistant and drug-responsive group.

Generalized and partial epilepsy (drug-resistant drug-responsive)

By comparing genotype frequencies between drug-resistant and drug-responsive patients after stratification by type of seizures, significant differences $(p<0.05)$ were observed for drug-responsive generalized and partial type of seizure for $1236 \mathrm{CT}$, while for $2677 \mathrm{GT}$ no statistically significant differences were noticed. After analysing $\mathrm{C} 1236 \mathrm{~T}$ compound genotypes $\mathrm{CC}$ vs $\mathrm{CT}+\mathrm{TT}$, significant differences ( $\mathrm{p}-0.01)$ were demonstrated for drug-responsive generalized epilepsy patients. Also, a significant association between $\mathrm{T}$ variant allele at the same 1236 locus and drug responsive patients was found ( $\mathrm{p}-0.03)$. (Table IV)

Total epileptic patients (drug-resistant/ drug-responsive)

When we considered $\mathrm{CC}$ as reference, 1236CT heterozygous was highly representative in the responsive group ( $\mathrm{p}-0.001)$ and $\mathrm{T}$ variant allele representative in the same group for the same SNP (p-0.04). No association between the G2677T polymorphism and epilepsy was found.

Compound genotype C1236T/G2677T $(\mathrm{CC}+\mathrm{GG} ; \mathrm{CT}+\mathrm{GT} ; \mathrm{TT}+\mathrm{TT})$ analysis showed that $\mathrm{CT}+\mathrm{TT}$ combination was three time more representative in drug-responsive epileptic groups compared with drug-resistant, with a significant $\mathrm{p}$ value of 0.001 (OR:3.43, 95\% CI:1.09-10.7).

By comparing genotype genetic models' (CC vs TT, CT vs TT, CC vs CT, $\mathrm{CC}+\mathrm{CT}$ vs TT,
$\mathrm{CC}$ vs CT+TT) effects in drug-resistant and in drug-responsive epileptic patients, assuming co-dominant (CC vs TT, CT vs TT), dominant $(\mathrm{CC}+\mathrm{CT}$ vs $\mathrm{TT})$ and recessive $(\mathrm{CC}$ vs $\mathrm{CT}+\mathrm{TT})$ we found a statistically significant association (p-0.001) of the 1236CC genotype with the drug-responsive group.

\section{Cryptogenic and idiopathic epilepsy}

(drug-resistant and drug-responsive)

When patients were stratified by aetiology of epilepsy our results showed an association of drug-responsive epilepsy with variant $\mathrm{T}$ allele and TT homozygous genotype in both analyzed polymorphisms. In both cases, the OR was $<1$, indicating TT as a possible protective factor in the development of unresponsive epilepsies (Table V). After stratification of idiopathic forms by type of seizure (partial and generalized) we obtained the following results: an association with homozygous variant genotype $1236 \mathrm{TT}$ with idiopathic partial and generalized drug-responsive group, with a statistically significant $\mathrm{p}$-value (0.04 and 0.05 respectively)

We assessed the association of MDR1 haplotypes derived from C1236T and G2677T loci in response to AEDs in drug-resistant and drug-responsive groups. There were 4 possible combinations (CG, CT, TG and TT) and they were estimated and compared between drug-resistant and drug-responsive groups. In both groups all haplotypes were represented higher than 5\%. Using as a reference the CG haplotype we did not find any statistical difference between the groups ( $>0.05$ ). In drug-resistant group CG was the most frequent $(36.1 \%)$ while in drug-responsive group TT haplotype was found to have a higher prevalence $(29.1 \%)$. In the healthy controls group haplotype frequencies were as follows: 29.6 for CG, 21.1 for CT, 20.5 for TG and 28.8 for TT. 
Table IV. Genotype and allele frequencies of C1236T and G2677T in drug-resistant and drug-responsive group

\begin{tabular}{|c|c|c|c|c|c|}
\hline Type of epilepsy & Genotype & Drug-responsive & Drug-resistant & $\mathrm{OR} / 95 \% \mathrm{CI}$ & p value* \\
\hline $\mathrm{ABCB} 1-\mathrm{C} 1236 \mathrm{~T}$ & & $\mathrm{n}-59$ & $n-23$ & & \\
\hline \multirow{6}{*}{ generalized } & $\mathrm{CC}$ & $14(23.7)$ & $12(52.2)$ & - & - \\
\hline & $\mathrm{CT}$ & $32(54.2)$ & $8(34.8)$ & $3.43(1.14-10.2)$ & 0.02 \\
\hline & TT & $13(22.1)$ & $3(13.0)$ & $3.71(0.85-16.2)$ & 0.10 \\
\hline & $\mathrm{CC} / \mathrm{CT}+\mathrm{TT}$ & $14 / 45$ & $12 / 11$ & $0.28(0.10-0.78)$ & 0.01 \\
\hline & C & $60(50.8)$ & $32(69.5)$ & - & - \\
\hline & $\mathrm{T}$ & $58(49.1)$ & $14(30.5)$ & $0.45(0.21-0.93)$ & 0.03 \\
\hline \multirow[t]{7}{*}{ Partial } & & n-24 & n-8 & & \\
\hline & $\mathrm{CC}$ & $2(8.3)$ & $3(37.5)$ & - & - \\
\hline & $\mathrm{CT}$ & $15(62.5)$ & $1(12.5)$ & $22.5(1.51-335.6)$ & 0.02 \\
\hline & TT & $7(29.2)$ & $4(50.0)$ & $2.62(0.29-23.1)$ & 0.59 \\
\hline & $\mathrm{CC} / \mathrm{CT}+\mathrm{TT}$ & $2 / 22$ & $3 / 5$ & $0.15(0.02-1.16)$ & 0.08 \\
\hline & C & $19(39.5)$ & $7(43.7)$ & - & - \\
\hline & $\mathrm{T}$ & $29(60.4)$ & $9(56.3)$ & $0.84(0.26-2.64)$ & 0.76 \\
\hline \multicolumn{6}{|l|}{ Total epilepsy } \\
\hline \multirow{7}{*}{ No 114} & $\mathrm{CC} / \mathrm{TT}$ & $16 / 20$ & $15 / 7$ & $0.37(0.12-1.13)$ & 0.07 \\
\hline & $\mathrm{CT} / \mathrm{TT}$ & $47 / 20$ & $9 / 7$ & $1.82(0.59-5.59$ & 0.28 \\
\hline & $\mathrm{CC} / \mathrm{CT}$ & $16 / 47$ & $15 / 9$ & $0.20(0.07-0.55)$ & 0.001 \\
\hline & $\mathrm{CC}+\mathrm{CT} / \mathrm{TT}$ & $63 / 20$ & $24 / 7$ & $0.91(0.34-2.45)$ & 0.86 \\
\hline & $\mathrm{CC} / \mathrm{CT}+\mathrm{TT}$ & $16 / 67$ & $15 / 16$ & $0.25(0.10-0.62)$ & 0.001 \\
\hline & C & $79(47.6)$ & $39(62.9)$ & - & - \\
\hline & $\mathrm{T}$ & $87(52.4)$ & $23(37.1)$ & $0.53(0.29-0.97)$ & 0.04 \\
\hline ABCB1-G2667T & & $n-59$ & $n-23$ & & \\
\hline \multirow[t]{6}{*}{ Generalized } & GG & $17(28.8)$ & $9(39.1)$ & - & - \\
\hline & GT & $28(47.5)$ & $11(47.8)$ & $1.38(0.46-3.92)$ & 0.58 \\
\hline & TT & 14 (23.7) & $3(13.1)$ & $2.47(0.55-10.9)$ & 0.30 \\
\hline & GG/GT+TT & $17 / 42$ & $9 / 14$ & $0.62(0.22-1.72)$ & 0.36 \\
\hline & G & $62(52.5)$ & $29(63.0)$ & - & - \\
\hline & $\mathrm{T}$ & $56(47.4)$ & $17(36.9)$ & $0.65(0.32-1.32)$ & 0.22 \\
\hline \multirow[t]{6}{*}{ Partial } & & $\mathrm{n}-24$ & n-8 & & \\
\hline & GG & $3(12.5)$ & $1(12.5)$ & - & - \\
\hline & GT & $12(50.0)$ & $2(25.0)$ & $2.0(0.13-30.2)$ & 0.98 \\
\hline & TT & $9(37.5)$ & $5(62.5)$ & $0.64(0.04-7.41)$ & 0.95 \\
\hline & GG/GG+TT & $3 / 21$ & $1 / 7$ & $1(0.08-1.25)$ & 0.97 \\
\hline & G & $18(37.5)$ & $4(25.0)$ & - & \\
\hline Total epilepsy & $\mathrm{T}$ & $30(62.5)$ & $12(75.0)$ & $1.83(0.5-6.76)$ & 0.54 \\
\hline & GG/TT & $20 / 23$ & $10 / 8$ & $0.69(0.23-2.1)$ & 0.51 \\
\hline & GT/TT & $40 / 23$ & $13 / 8$ & $1.07(0.38-2.96)$ & 0.89 \\
\hline & $\mathrm{GG} / \mathrm{GT}$ & $20 / 40$ & $10 / 13$ & $0.65(0.24-1.74)$ & 0.38 \\
\hline & $\mathrm{GG}+\mathrm{GT} / \mathrm{TT}$ & $60 / 23$ & $23 / 8$ & $0.90(0.35-2.31)$ & 0.83 \\
\hline & GG/GT+TT & $20 / 63$ & $10 / 21$ & $0.66(0.26-1.65)$ & 0.37 \\
\hline & G & $80(48.2)$ & $33(53.2)$ & - & - \\
\hline & $\mathrm{T}$ & $86(51.8)$ & $29(46.7)$ & $0.81(0.45-1.46)$ & 0.45 \\
\hline \multicolumn{6}{|l|}{$\begin{array}{l}\text { Compound genotype } \\
\text { C1236T/G2677T }\end{array}$} \\
\hline $\mathrm{CC}+\mathrm{GG}$ & & $12(14.4)$ & $10(32.2)$ & - & - \\
\hline $\mathrm{CT}+\mathrm{GT}$ & & $33(39.7)$ & $8(25.8)$ & $3.43(1.09-10.7)$ & 0.03 \\
\hline $\mathrm{TT}+\mathrm{TT}$ & & $12(14.4)$ & $6(19.3)$ & $1.66(0.45-6.05)$ & 0.43 \\
\hline
\end{tabular}

*chi test square, OR-Odds Ratio, n-number 
Table V. Genotype association of C1236T and G2677T in drug-resistant and drug-responsive group after aetiology stratification

\begin{tabular}{|c|c|c|c|c|c|}
\hline \multicolumn{2}{|c|}{$\begin{array}{l}\text { ABCB1genotype } \\
\text { Idiopathic(N-74) }\end{array}$} & $\begin{array}{c}\text { Drug resistant } \\
(\%)(\mathrm{N}-14) \\
\end{array}$ & $\begin{array}{c}\text { Drug responsive } \\
(\%)(\mathrm{N}-60) \\
\end{array}$ & $p$ value & $\mathrm{OR} / 95 \% \mathrm{CI}$ \\
\hline \multirow[t]{5}{*}{$\mathrm{C} 1236 \mathrm{~T}$} & $\mathrm{CC}$ & $10(71.4)$ & $9(15.0)$ & - & - \\
\hline & $\mathrm{CT}$ & $3(21.4)$ & $34(56.7)$ & 0.002 & $0.07(0.01-0.35)$ \\
\hline & TT & $1(7.14)$ & $17(28.3)$ & 0.003 & $0.05(0.005-0.48)$ \\
\hline & $\mathrm{C}$ & $23(82.1)$ & $52(43.3)$ & - & - \\
\hline & $\mathrm{T}$ & $5(17.8)$ & $68(56.7)$ & 0.001 & $0.13(0.04-0.45)$ \\
\hline \multirow[t]{5}{*}{$\mathrm{G} 2677 \mathrm{~T}$} & GG & $6(42.8)$ & $14(23.4)$ & - & - \\
\hline & GT & $7(51.3)$ & $26(43.3)$ & 0.47 & $0.62(0.17-2.93)$ \\
\hline & $\mathrm{TT}$ & $1(7.14)$ & $20(33.3)$ & 0.04 & $0.11(0.01-1.08)$ \\
\hline & G & $19(66.1)$ & $54(45.0)$ & - & - \\
\hline & $\mathrm{T}$ & $9(33.9)$ & $66(55.0)$ & 0.03 & $0.38(0.16-0.92)$ \\
\hline \multicolumn{2}{|c|}{$\begin{array}{l}\text { ABCB1genotype } \\
\text { Cryptogenic } \\
\text { (N-40) }\end{array}$} & $\begin{array}{l}\text { Drug resistant (\%) } \\
(\mathrm{N}-17)\end{array}$ & $\begin{array}{l}\text { Drug responsive }(\%) \\
\qquad(\mathrm{N}-23)\end{array}$ & p value & $\mathrm{OR} / \mathbf{9 5} \% \mathrm{CI}$ \\
\hline \multirow[t]{5}{*}{$\mathrm{C} 1236 \mathrm{~T}$} & $\mathrm{CC}$ & $5(29.4)$ & $7(30.4)$ & - & - \\
\hline & $\mathrm{CT}$ & $6(35.3)$ & $13(56.5)$ & 0.70 & $0.64(0.14-2.90)$ \\
\hline & TT & $6(35.3)$ & $3(13.4)$ & 0.38 & $2.8(0.46-16.9)$ \\
\hline & $\mathrm{C}$ & $23(82.1)$ & $19(41.3)$ & - & - \\
\hline & $\mathrm{T}$ & $4(17.8)$ & $27(58.7)$ & 0.0002 & $0.12(0.03-0.41)$ \\
\hline \multirow[t]{5}{*}{ G2677T } & GG & $4(23.5)$ & $6(26.1)$ & - & - \\
\hline & GT & $6(35.3)$ & $14(60.8)$ & 0.69 & $0.64(0.13-3.14)$ \\
\hline & TT & $7(41.2)$ & $3(13.1)$ & 0.36 & $3.5(0.54-22.3)$ \\
\hline & G & $20(58.8)$ & $26(56.2)$ & - & - \\
\hline & $\mathrm{T}$ & $14(41.2)$ & $20(43.8)$ & 1.00 & $0.91(0.37-2.23)$ \\
\hline
\end{tabular}

\section{Discussion}

As a result of the clinical characteristics of drug-resistant epileptic patients, we found a predominance in younger children, meaning $54.9 \%$ were younger than four years old. With respect the aetiology, $87.7 \%$ of the cases had a normal neurological examination without structural lesions, identifiable on computer tomography (CT) or MRI, while $12.3 \%$ had nonspecific global developmental delay or mental retardation before epilepsy onset but with no identifiable structural cause for epilepsy on neuroimaging.

Idiopathic epilepsies may have a genetic etiology, but the genetic defect is associated with a distinctive pathology that predisposes to seizures.[18] This type of epilepsy is distinguished from diseases with genetic determinism in which seizures are part of that syndrome. Recurrent seizures can be caused by genetic predisposition, or by neuropathological, chemical and physiological changes of nerve cells and at the connections between them. Seizures can be caused by any lesion involving the cortex. Damage may be structural, metabolic, or may involve the neurotransmitters or the ion channels. There are epilepsies caused entirely by genetic factors and epilepsies determined by lesion factors, congenital or acquired, but most often these factors are acting together in varying proportions. The therapeutic effect of a drug is the consequence of its action on several locations of the brain cell. Resistance to anti-epileptics may be caused by functional or structural alterations of the action site 
that may change the pharmacodynamics of the drug. These molecular AED targets behave like ligands and can be divided into two categories: voltage-dependant channels and neurotransmitter receptors associated with neuronal excitation. The changes produced at the site of action can be determined or developed as a result of epigenetic changes (mutations of genes dependent channel - channelopathies) or caused by exogenous environmental factors. [19]

The action mechanism of antiepileptic drugs is not fully understood. Three important categories of potential candidate genes that can influence the response of AEDs are being discussed: genes encoding transporters of drugs whose known substrate is an antiepileptic; genes encoding for enzymes that are involved in the metabolism of AEDs decomposition; and genes encoding AEDs targets.[18,20]

IGE treatment is demanding for two main reasons. Firstly, AEDs beneficial in focal epilepsies may be deleterious in IGEs. Secondly, the efficacy of AEDs differs even within IGE seizures. This is because of the generation of absences, for example, are due to a predominance of inhibitory activity, in contrast to generalized convulsive seizures in which an excess of excitatory activity is present. Difficulties in diagnosis can generate wrong management of AED that can negatively impact the development of drugs. So, there may be situations where partial epilepsy forms are interpreted as generalized, which require a certain type of antiepileptic administration. Certain AEDs that are beneficial in focal epilepsies are ineffective or even contraindicated in IGE. A drug that is efficient in one type of generalized seizure may be ineffective or exacerbate another type of generalized seizure.[20] Some epilepsy forms are characterized by polymorphic seizures; in those situations seizure exacerbation induced by the AED used must be considered as not always parents/tutors can correctly identify all seizures of a child. Therefore, identification of type of epilepsy must be done with great care, and only by correlating clinical and EEG data.

In recent years numerous scientists have studied the role of MDR1 gene in relation to antiepileptic drug response, the fact that certain AEDs are a substrate for MDR1 being wellknown. Therefore, various studies are needed, involving groups from all this categories (in relationship to substrate medication - epilepsy type - patient age). Certain AEDs are P-glycoprotein inhibitors and $\mathrm{ABCB} 1$ polymorphisms influence this inhibitory effect, the intracellular P-glycoprotein substrate concentration depending on one hand on these gene polymorphisms and on the other hand on the drug combination administered (substrate and inhibitor).[21] The protein overexpression in resistant cases may not be related to therapy response. Following experimental tests on mice and rats it was proven that seizures influence the p-gp level and that it is possible for certain changes highlighted in resistant forms to be the result of increased seizure frequency.[22]

The results from various studies concerning the role of ABCB1 gene polymorphisms in antiepileptic drug responsiveness are conflicting. [23,24] Seo et al.[25] found that 2677TT genotype was significantly higher than GG genotype in drug-resistant patients. He also found that $1236 \mathrm{CC}-2677 \mathrm{GG}$ dyplotype association was lower in drug-resistant patients in comparison to drug-responsive epileptic patients. Other researchers found an associated G2677T SNP with resistant epilepsy.[26,27] Contradicting with these results, Seven et al. . and Haerian et al. found no association between these SNPs and drug-resistant epilepsy.[28,29] In our study we found an association of the TT genotype variant of $\mathrm{C} 1236 \mathrm{~T}$ and also G2677T with responsive epileptic patients. Contradictions regarding the presence or absence of association between these polymorphisms and resistant epilepsies can be explained by differences related to the inclusion 
criteria. A number of authors included different forms of epilepsy with different etiology, including symptomatic forms, many cases from those being resistant to multiple AEDs. We also tried to make an analysis of all epileptic patients initially selected, but no correlation between seizure control and MDR1 gene polymorphisms was found.

For these two gene polymorphisms ethnic differences have been reported, the frequency of $\mathrm{C}$ and $\mathrm{T}$ alleles varying between $45-55 \%$ in Caucasian populations and between $5-10 \%$ in African, Americans and Indians. [30] Many researchers have been concerned with the genotypic effects of these polymorphisms on drug resistance in epilepsy. The conflicting reports of several studies on genotype and allele frequency may be due to ethnic differences, knowing that gene polymorphisms often vary among ethnic groups, thus affecting the result of genetic studies.[28]

Our findings are in partial agreement with these results, as we found the same differences between 1236CC and 1236TT genotypes distribution in our study groups. Thus, $1236 \mathrm{CC}$ was more frequent in resistant group compared with responsive patients (48.4 vs 19.3), while TT has been identified more frequent in responsive group (24.1 vs 22.6). With regard to G2677T, the same distribution was found: GG genotype was more frequent in resistant group (32.2 vs 24.1) while TT more frequent in responsive one (27.7 vs 25.8). Contradictory results were found by Seo et al. [25] who noticed that patients with drug-resistant epilepsy had a higher frequency of 2677TT genotypes in comparison to drug-responsive patients (26.2 vs 23.8 , respectively). In a Ukbek study conducted by Tuychibaeva et al.[31] C1236T SNP distribution among patients with pharmacoresistant epilepsy and healthy individuals was compared and the $1236 \mathrm{CT}$ genotype was found most common, with a frequency of $54.2 \%$ in epileptic patients and $40 \%$ in healthy controls. TT variant homozygous genotype also occurred with a high frequency in the control group (53.3\% vs $33.9 \%$ in epileptic group, with a significant statistic $p$ value $p-0.03$ ). Same results occurred in our study, 1236CT genotype being most common, both in the control and in the epileptic children groups (51.0 and 49.1 respectively).

By comparing C1236T and G2677T polymorphisms' allele, genotype and haplotype frequencies, our results were similar to those reported by other studies on different populations. For example, in our study $1236 \mathrm{C}$ allele had a frequency of $51.6 \%$ in healthy population, same results being reported in Macedonians (56\%), Serbians (53\%), Germans and Hungarians $(55 \%)$ but not in a gipsy (44\%) and Slovenians (39\%) [32-34]. 2677G allele frequency in our study was found in $51 \%$ of patients, similar to other European populations (from 53 to $56 \%$ ). $[35,36]$ No significant differences between $\mathrm{C} / \mathrm{T}$ and $\mathrm{G} / \mathrm{T}$ were detected in our study, in contradiction with other studies previously published on Asian populations.[37,38] A strong association for C1236T and G2677T linkage disequilibrium was observed in a Macedonian study.[32] When we analysed the linkage between these two SNPs the most frequent genotype we found was CT/GT, followed by CC/GG and TT/TT, but no statistical differences were detected between the study groups or associated with drug-resistant epilepsy. In a study conducted in Romania, using a group of 70 epileptic children with idiopathic and symptomatic epilepsy, in which three MDR1 polymorphisms (C3435T, G2677T and C129T) were monitored, Buzoianu et al. did not succeeded demonstrate association of these polymorphisms to drug resistant epilepsy, even after patients on monoterapy selection. [3,39] When we analyzed the entire epileptic group, as a drug-resistant and drug-responsive patients we noticed the same results as the previously mentioned study reported [3] regarding G2677T, but we found a statistically significant association of the 1236CT genotype with drug-responsive ep- 
ilepsy (p-0.001). When we analyzed those two groups after stratification by aetiology we found an association between CC/CT and GG homozygous in both SNPs with idiopathic resistant epilepsy patients. The allele $\mathrm{T}$ variant was also representative in those two groups. No associations between genotype or allele with cryptogenic forms were identified. These results are in contradiction with data published by Sanchez et al. where this association was present but in symptomatic, not in idiopathic epilepsies.[4]

A highly significant linkage disequilibrium was shown among exons 12, 21, 26 in MDR1 gene (C1236T, G2677T, C3435T). [17] Naumovska et al.[32] concluded in their study that CG haplotype was over-represented in the study population, followed by TT haplotype. In our study, CT/GT haplotypes derived from C1236T and $\mathrm{G} 2677 \mathrm{~T}$ polymorphisms were associated with response to antiepileptic treatment, with a statistical significance of $\mathrm{p}-0.03$, but we found the same associations as those previously described, in our control group.

An important aspect that must be considered is related to the inclusion criteria and in particular the definition of drug-resistance and drug-responsiveness, a situation that can be held responsible for the conflicting results of studies conducted to date. Compared to studies with the same inclusion criteria our results are in accordance, as we found no difference in allele frequency and also no risk of developing resistant epilepsy for epileptic patients with TT genotype in none of the two analysed mutations.

The limitation of the current study was the small sample size, due to the fact that not all diagnosed patients had signed an informed consent. In addition, neuroimaging investigation are not widely used and not all cases with the clinical diagnosis of idiopathic or cryptogenic epilepsy can benefit from such an examination, therefore those cases being excluded from the study.
To clarify the exact clinical implication of MDR1 polymorphisms in multidrug resistant epilepsy, further investigations in various types of epilepsy, with a reduced number of antiepileptic drugs, would be necessary.

MDR1 C1236T mutation was determined for the first time in a Romanian children population, as well as the association of these two SNPs.

\section{Conclusion}

Our results show that MDR1 C1236T and G2677T polymorphisms are not associated with drug-resistant epilepsy in the study population. On the other hand, following the aetiological classification 1236TT and 1236CT genotype variants and also 2677TT were found to be significantly associated with drug-responsive patients diagnosed with idiopathic epilepsy, but not with patients diagnosed with cryptogenic forms.

\section{Acknowledgements}

This paper was published under the frame of European Social Found, Human Resources Development Operational Programme 2007-2013, project no. POSDRU/159/1.5/S/136893.

The authors thank all staff and technicians who helped recruit the patients and collect blood samples for this study.

\section{References}

1. Kwan P. Schachter SC, Brodie MJ. Drug-resistant epilepsy. N. Engl J Med. 2011 Sept;365(10):912-6. DOI: 10.1056/NEJMra1004418

2. Löscher W.How to explain multidrug resistance in epilepsy? Epilepsy Curr. 2005 May-Jun;5(3):107-12. DOI: 10.1111/j.1535-7511.2005.05311.x

3. Buzoianu AD, Sabin O, Bocşan CI, Militaru C. MDR gene polymorphism and refractory epilepsy. Therapeutics, Pharmacology and Clinical Toxicology. 2009;13(4):375-80.

4. Sánchez MB, Herranz JL, Leno C, Arteaga R, Oterino A, Valdizán EM, Nicolás JM, et al. Genetic factors as- 
sociated with drug-resistance of epilepsy: relevance of stratification by patient age and aetiology of epilepsy. Seizure. 2010 Mar;19(2):93-101. DOI: 10.1016/j.seizure.2009.12.004

5. Thishler DM, Weinberg KI, Hinton DR, Barbaro N, Annet GM, Raffael C. MDR1 gene expression in brain of patients with medically intractable epilepsy. Epilepsia. 1995 Jan;36(1):1-6. DOI: 10.1111/j.1528-1157.1995. tb01657.x

6. Dombrovski SM, Desai SJ, Marroni M, Cucullo L, Goodrich K, Bingaman W, et al. Overexpression of multidrug resistance genes in endothelial cell from patients with refractory epilepsy. Epilepsia. 2001 Dec;42(12):1501-6. DOI: 10.1046/j.15281157.2001.12301.x

7. Siddiqui A, Kerb R, Weale ME, Brinkmann U, Smith A, Goldstein DB, et al. Association of multidrug resistance in epilepsy with a polymorphism in the drug-transporter gene ABCB1. N Engl J Med. 2003 Apr;348(15):14428. DOI: $10.1056 / \mathrm{NEJMoa} 021986$

8. Kim DW, Kim M, Lee SK, Kang R, Lee SY. Lack of association between $\mathrm{C} 3435 \mathrm{~T}$ nucleotide MDR1 genetic polymorphism and multidrug-resistant epilepsy. Seizure. 2006 Jul;15(5):344-7. DOI: 10.1016/j.seizure.2006.02.015

9. Lakhan R, Misra UK, Kalita J, Pradhan S, Gogtay NJ, Singh MK, et al. No association of ABCB1 polymorphisms with drug-refractory epilepsy in a north Indian population. Epilepsy Behav. 2009 Jan;14(1):78-82. DOI: 10.1016/j.yebeh.2008.08.019

10. Bournissen FG, Moretti ME, Juurlink DN, Koren G, Walker M, Finkelstein Y. Polymorphism of the MDR1/ABCB1 C3435T drug-transporter and resistance to anticonvulsant drugs: a meta-analysis. Epilepsia. 2009 Apr;50(4):898-903. DOI: 10.1111/j.15281167.2008.01858.x

11. Saygi S, Alehan F, Atac FB, Erol I, Verdi H, Erdem R. Multidrug resistance 1 (MDR1) 3435C/T genotyping in childhood drug-resistant epilepsy. Brain Dev. 2014 Feb;36(2):137-42. DOI: 10.1016/j.braindev.2013.01.016

12. Commission on Classification and Terminology of the International League Against Epilepsy. Proposal for revised classification of epilepsies and epileptic syndromes. Epilepsia 1989;30:389-99. DOI: 10.1111/ j.1528-1157.1989.tb05316.x

13. Kwan P, Arzimanoglou A, Berg AT, Brodie MJ, Al- len Hauser W, Mathern G, et al. Definition of drug resistant epilepsy: consensus proposal by the ad hoc Task Force of the ILAE Commission on Therapeutic Strategies. Epilepsia. 2010 Jun;51(6):1069-77. DOI: 10.1111/j.1528-1167.2009.02397.x

14. Hao X, Goldberg D, Kelly K, Stephen L, Kwan P, Brodie MJ. Uncontrolled epilepsy is not necessarily the same as drug-resistant epilepsy: differences between populations with newly diagnosed epilepsy and chronic epilepsy. Epilepsy Behav. 2013 Oct;29(1):4-6. DOI: 10.1016/j.yebeh.2013.06.019

15. Dong L, Luo R, Tong Y, Cai X, Mao M, Yu D. Lack of association between $\mathrm{ABCB} 1$ gene polymorphism and pharmacoresistant epilepsy: An analysis in a western Chinese pediatric population. Brain Res. 2011 May;91(13):114-24. DOI: 10.1016/j.brainres.2011.03.028

16. Marusteri M, Bacarea V. Kako odabrati pravi test za procjenu statističke značajnosti razlike između skupina?/ Comparing groups for statistical differences: how to choose the right statistical test? Biochem Med. 2010;20(1):15-32. DOI: 10.11613/BM.2010.004

17. Shorvon SD. The etiological classification of epilepsy. In Shorvon SD, Andermann F, Guerrini R (Eds). The causes of epilepsy. Common and uncommon causes in adults and children. Cambridge University Press, Cambridge, 2011b; 21-23. DOI: 10.1017/CBO9780511921001 DOI: $10.1017 / \mathrm{CBO} 9780511921001.004$

18. Berg AT, Berkovic SF, Brodie MJ, Buchhalter J, Cross HJ, van Emde BW, Engel J Jr, et al. Revised terminology and concepts for organization of seizures and epilepsies: report of the ILAE Commission on Classification and Terminology, 2005-2009. Epilepsia 2010;51(4):676-85. DOI: $10.1111 /$ j.1528-1167.2010.02522.x

19. Juárez IM, Vanegas LE, Rodríguez NR, Aldana JAL, Escueta AVD. Gene involved in Pharmacoresistant epilepsy, in Rocha L, Cavalheiro EA (eds.), Pharmacoresistance in Epilepsy: From Genes and Molecules to Promising Therapies. Springer Science-Business Media, LLC. 2013:11-25 ISBN: 978-1-4614-6463-1 DOI: 10.1007/978-1-4614-6464-8_2

20. Berg AT. Epilepsies. In Panayiotopoulos CP (Ed). Atlas of epilepsies. Vol 2. Springer. London 2010:732-756 DOI: 10.1007/978-1-84882-128-6_2

21. Sisodiya SM, Lint WR, Harding BN, Squier MV, Thom M. Drug resistance in epilepsy: human epilepsy. Novartis Found Symp. 2002;243:167-74; discussion 174- 
9, 180-5.

22. Löscher W, Klotz U, Zimprich F, Schmidt D. The clinical impact of pharmacogenetics on the treatment of epilepsy. Epilepsia 2009;50:1-23. DOI: 10.1016/ S0920-1211(02)00062-1 DOI: $10.1111 / \mathrm{j} .1528-$ 1167.2008.01716.x

23. Brandt C, Bethmann K, Gastens AM, Löscher W. The multidrug transporter hypothesis of drug resistance in epilepsy: Proof-of-principle in a rat model of temporal lobe epilepsy. Neurobiol Dis. 2006 Oct;24(1):202-1. DOI: 10.1016/j.nbd.2006.06.014

24. Das A, Balan S, Banerjee M, Radhakrishnan K. Drug resistance in epilepsy and the $\mathrm{ABCB} 1$ gene: The clinical perspective. Indian J Hum Genet.2011 May;17(4):1221. DOI: $10.4103 / 0971-6866.80353$

25. Seo T, Ishitsu T, Ueda N, Nakada N, Yurube K, Ueda $\mathrm{K}$, et al. ABCB1 polymorphisms influence the response to antiepileptic drugs in Japanese epilepsy patients. Pharmacogenomics. 2006 Jun;7(4):551-61. DOI: 10.2217/14622416.7.4.551

26. Sporis D, Basic S, Bozina N, Babic T, Hajnsek S, Sertic J, et al. ABCB1 gene variants as predictors of drug resistant epilepsy in Croatian population. Neurol. Croat.2011;60(2):63-9.

27. Zimprich F, Sunder-Plassmann R, Stogmann E, Gleiss A, Dal Bianco A, Zimprich A, et al. Association of an ABCB1 gene haplotype with pharmacoresistance in temporal lobe epilepsy. Neurology. 2004 Sep;63(6):10879. DOI: 10.1212/01.WNL.0000141021.42763.F6

28. Seven M, Batar B, Unal S, Yesil G, Yuksel A, Guven M. The drug-transporter gene MDR1 C3435T and G2677T/A polymorphisms and the risk of multidrug resistant epilepsy in Turkish children. Mol Biol Rep. 2014 Jan;41(1):331-6. DOI: 10.1007/s11033-0132866-y

29. Haerian BS, Lim KS, Tan HJ, Mohamed E, Tan CT, Raymond AA, et al. Association between ABCB1 polymorphism and response to sodium valproate treatment in Malaysian epilepsy patients. Epileptic Disord. 2011 Mar;13(1):65-75.

30. Vahab SA, Sen S, Ravindran N, Mony S, Mathew A, Vijayan N, et al. Drug Metab Pharmacokinet. 2009;24(3):255-60. DOI: 10.2133/dmpk.24.255

31. Tuychibaeva NM, Karimov K.Ya, Alimakhodjaeva PR, Prokhorova AV, Shamsutdinova DB, Boboev KT. MDR1 gene C3435T and C1236T polymorphism among patients with pharmacoresistant epilepsy and healthy individuals . International Journal of BioMedicine. 2014 Dec;4(4):209-12.

32. Naumovska Z, Nestorovska AK, Sterjev Z, Filipce A, Dimovski A, Suturkova L. Genotype variability and haplotype profile of ABCB1 (MDR1) gene polymorphism in Macedonian population. Prilozi.2014;35(3):121-33.

33. Milojkovic M, Stojnev S, Jovanovic I, Ljubisavljevic S, Stefanovic V, Sunder-Plassman R. Frequency of the C1236T, G2677T/A and C3435T MDR1 gene polymorphisms in the Serbian population. Pharmacol Rep. 2011;63(3):808-14. DOI: 10.1016/S17341140(11)70593-X

34. Sipeky C, Csongei V, Jaromi L, Safrany E, Maasz A, Takacs I, Beres J, et al. Genetic variability and haplotype profile of MDR1 (ABCB1) in Roma and Hungarian population samples with a review of the literature. Drug Metab Pharmacokinet.2011;26(2):206-15. DOI: 10.2133/dmpk.DMPK-10-SC-068

35. Petrova DT, Nedeva P, Maslyankov S, Toshev S, Yaramov N, Atanasova S, et al. No association between MDR1 (ABCB1) 2677G $>\mathrm{T}$ and $3435 \mathrm{C}>\mathrm{T}$ polymorphism and sporadic colorectal cancer among Bulgarian patients. Cancer Res Clin Oncol. 2008 Mar;134(3):31722. DOI: $10.1007 / \mathrm{s} 00432-007-0279-9$

36. Gaikovitch EA, Cascorbi I, Mrozikiewicz PM, Brockmöller J, Frötschl R, Köpke K, et al. Polymorphisms of drug-metabolizing enzymes CYP2C9, CYP2C19, CYP2D6, CYP1A1, NAT2 and of P-glycoprotein in a Russian population. Eur J Clin Pharmacol. 2003 Aug; 59(4):303-12. DOI: 10.1007/s00228-003-0606-2

37. Lee SS, Kim SY, Kim WY, Thi-Le H, Yoon YR, Yea SS, et al. MDR1 genetic polymorphisms and comparison of MDR1 haplotype profiles in Korean and Vietnamese populations. Ther Drug Monit. 2005 Aug;27(4):531-5. DOI: 10.1097/01.ftd.0000164293.75854.11

38. Estrela RC, Ribeiro FS, Carvalho RS, Gregório SP, Dias-Neto E, Struchiner CJ, et al. Distribution of ABCB1 polymorphisms among Brazilians: impact of population admixture. Pharmacogenomics. 2008 Mar;9(3):26776. DOI: 10.2217/14622416.9.3.267

39. Buzoianu A, Bocsan IC, Maier C, Trifa AP, Poop RA, Perju Dumbrava L, et al. Genotype-phenotype correlation between the alleles of the MDR1 C3435T polymorphism and pharmackochinetic parameters in Romanian epileptic patients. Therapeutics Pharmacology and Clinical Toxicology. 2011 Mar;15(1):40-4. 